\title{
The Benefits of Financial Ratios' as the Indicators of Future Bankruptcy on the Economic Crisis
}

\author{
Setia Mulyawan ${ }^{1}$ \\ 1 Student of Graduate Program, Padjadjaran University, Bandung, Indonesia. \\ Lecturer of Department of Management, Islamic State University Sunan Gunung Djati, Bandung, \\ Indonesia \\ Email:mail2setia@gmail.com
}

\begin{abstract}
It is proved that financial ratios can predict future bankruptcy even on high uncertainty conditions such as an economic crisis. The research indicates that the accuracy of prediction is more increasing in line with a coming bankruptcy. The result of the research shows that four years before a corporate becomes bankrupt there have been significant differences of financial ratios between bankrupt company and sustained one. The ratios of liquidity, profitability, activity, and return on investment of sustained company are higher; while the leverage ratio is lower. The dominant influencing financial ratios toward a bankruptcy are liquidity and leverage ratios. The research finds that from ten tested ratios, Current Asset to current liabilities and total liabilities to total asset are the dominant financial ratios.
\end{abstract}

Keywords: bankruptcy, financial ratios, prediction models

\section{A. INTRODUCTION}

Financial ratios are believed to be used to predict the company in the future. Empirical evidence of the benefits of financial ratios to predict bankruptcy obtained from several studies such as Pankoff and Virgil (1970), Sinkey, (1975) which proves that the financial ratios proved accurate in setting the bank rating Whalen and Thomson (1988). In Indonesia, Mas'ud (1994) and Surifah (1999) through his research has also obtained the conclusion that the beneficial financial ratios to predict earnings growth and bank failures. To prove that the financial ratios can be used to predict corporate bankruptcy, the other researchers such as; Beaver (1966), Altman (1968), Dambolena and Khoury(1980), Thomson (1991), Zain (1994), Surifah (2000), and Avianti (2000) lead to the conclusion that the financial ratios useful for predicting corporate bankruptcy.

In 1997-1998 Indonesia's economic crisis that affects up to 2002. This study is intended to determine the benefits of financial ratios to predict bankruptcy in the business environment of high uncertainty. The purposes of this study are: (1) Is there a difference in the average financial ratios of bankrupt companies with companies not bankrupt; (2) Is the financial ratios can be used as a tool for predicting bankruptcy; and (3) Financial ratios are most influential to the bankruptcy of the company.

Financial ratios are believed to be used to predict the state of the company in the future. Empirical evidence about the benefits of financial ratios to predict bankruptcy has been demonstrated through several studies. Some experts who have done research on this, among others; Pankoff and Virgil (1970), as well as Sinkey, (1975) which proves that the financial ratios proved to be accurate in 
preparing the bank rating Whalen and Thomson (1988). In Indonesia, Mas'ud (1994) and Surifah (1999) through his research has also obtained the conclusion that the beneficial financial ratios to predict earnings growth and bank failures. Moreover, to prove that the financial ratios can be used to predict corporate bankruptcy, other researchers such as; Beaver (1966), Altman (1968), Dambolena and Khoury, (1980), Thomson (1991), Zain (1994), Surifah (2000), and Avianti (2000) through his research has obtained the conclusion that the beneficial financial ratios to predict bankruptcy of a company.

Evidence of the reliability of financial ratios in predicting bankruptcy of the company, among others, it is shown by the results of research Akhyar and Taufiq( 2001) who analyzed the accuracy Altman method in predicting the occurrence of liquidation of banks in Indonesia. The results of this study indicate that a Z-score liquidated banks is much smaller than the value of the Z-score of the banks are not liquidated. The results of this study concluded that Altman method can be used to predict the likelihood of liquidation on banking institutions.

\section{B. METHODS}

To answer the first purposes of research used univariate analysis to determine the difference of average between the two groups. To know the second purposes of the study used logistic regression models. The method used is the Backward-Stepwise (Wald) with a statistical model as follows:

$$
p=\frac{1}{1+e^{-\left(\beta_{0}+\beta_{1}+\ldots+\beta 0 X n\right)}}
$$

where ls:

$\mathrm{p} \quad=$ probability of bankruptcy

$\mathrm{e} \quad=$ the natural logarithm

Bo = constant

$\beta_{\mathrm{i}} \quad=$ logistic regression coefficient

$\mathrm{x}_{\mathrm{i}} \quad$ = financial ratios

To answer the third purposes of this research used Backward-Stepwise Logistic Regression using financial ratios for five years (1997-2001).

\section{RESULTS AND DISCUSSIONS}

\section{The difference of average Financial Ratios (1997-2001)}

The results of the normality test of data and different test to the financial ratios (1997-2001) are presented in the Table 1. Normality test results indicate that the $p$-value for all financial ratios tested were below 0.05 . Based on this result, the entire financial ratios were tested using the Mann Whitney $U$ statistical summary of different test results are presented in the Table 2.

Different test results using the Mann Whitney $U$ test statistics as presented in Table 2 show that 9 of financial ratios to obtain p-value less than 0.05 , which means that there are differences in average financial ratios of Current Assets to Current Liabilities, Quick Assets to Current Liabilities, Gross profit to Sales, Net Income to Sales, Sales to Total Assets, Sales to Fixed Assets, Earnings Before Interest and Taxes to Total Assets, Net Income to Total Assets and Total Liabilities to Total Assets of the 
bankrupt company with a company that does not bankrupt. The ratio of Cost of Goods Sold to Inventory does show non-significant difference indicated by the p-value greater than 0.05 .

Table 1: Results of Normality Test

\begin{tabular}{|c|c|c|c|c|c|c|}
\hline \multirow{2}{*}{ Num } & \multirow{2}{*}{ Financial Ratios } & \multirow{2}{*}{ Var. } & \multicolumn{3}{|c|}{ Kolmogorov-Smirnov (a) } & \multirow{2}{*}{ Result } \\
\hline & & & Stat. & $\mathrm{db}$ & p-value & \\
\hline 1 & Current Assets to Current Liabilities & $\mathrm{x} 1$ & .252 & 200 & .000 & Sig. \\
\hline 2 & Quick Assets to Current Liabilities & $x 2$ & .249 & 200 & .000 & Sig. \\
\hline 3 & Gross Profit to Sales & $x 3$ & .235 & 200 & .000 & Sig. \\
\hline 4 & Net Income to Sales & $x 4$ & .290 & 200 & .000 & Sig. \\
\hline 5 & Cost of Goods Sold to Inventory & $x 5$ & .256 & 200 & .000 & Sig. \\
\hline 6 & Sales to Total Assets & $x 6$ & .137 & 200 & .000 & Sig. \\
\hline 7 & $\begin{array}{l}\text { Sales to Fixed Assets } \\
\text { Earning Before Interest and Taxes }\end{array}$ & $\mathrm{x} 7$ & .288 & 200 & .000 & Sig. \\
\hline 8 & to Total Assets & $x 8$ & .160 & 200 & .000 & Sig. \\
\hline 9 & Net Income to Total Assets & $x 9$ & .182 & 200 & .000 & Sig. \\
\hline 10 & Total Liabilities to Total Assets & $x 10$ & .186 & 200 & .000 & Sig. \\
\hline
\end{tabular}

Source: Research Data Processing, 2014

Table 2: Results of Different Test (1997-2001)

\begin{tabular}{|c|c|c|c|c|c|c|}
\hline \multirow{2}{*}{ Num } & \multirow{2}{*}{ Financial Ratios } & \multirow{2}{*}{ Var. } & \multicolumn{3}{|c|}{ Result of Test } & \multirow{2}{*}{ Result } \\
\hline & & & Test *) & Stat. & p-value & \\
\hline 1 & Current Assets to Current Liabilities & $x 1$ & MW-U & 1955.0 & .000 & Sig. \\
\hline 2 & Quick Assets to Current Liabilities & $x 2$ & MW-U & 1928.0 & .000 & Sig. \\
\hline 3 & Gross Profit to Sales & $x 3$ & MW-U & 3458.0 & .000 & Sig. \\
\hline 4 & Net Income to Sales & $x 4$ & MW-U & 2682.0 & .000 & $\begin{array}{l}\text { Sig. } \\
\text { Non- }\end{array}$ \\
\hline 5 & Cost of Goods Sold to Inventory & $x 5$ & MW-U & 4750.0 & .541 & Siq. \\
\hline 6 & Sales to Total Assets & $x 6$ & MW-U & 3926.0 & .009 & Sig. \\
\hline 7 & $\begin{array}{l}\text { Sales to Fixed Assets } \\
\text { Earnings Before Interest and Taxes }\end{array}$ & $x 7$ & MW-U & 3779.0 & .003 & Sig. \\
\hline 8 & to Total Assets & $x 8$ & MW-U & 2305.0 & .000 & Sig. \\
\hline 9 & Net Income to Total Assets & $x 9$ & MW-U & 2561.0 & .000 & Sig. \\
\hline 10 & Total Liabilities to Total Assets & $\mathrm{x} 10$ & MW-U & 1656.0 & .000 & Sig. \\
\hline
\end{tabular}

$\left.{ }^{*}\right) \mathrm{MW}-\mathrm{U}=$ Mann Whitney U

Source: Results of Research Data Processing, 2014

Table 3 show that 9 financial ratios differed significantly between bankrupt companies with companies sustained. Financial ratios of liquidity, profitability, activity, and Return on Investment from companies that are not bankrupt greater than the bankrupt companies. While the leverage ratio (Total Liabilities to 
Total Assets) companies that sustained smaller than the bankrupt companies. Resume different test results of financial ratios studied are presented in the Table 4. Table 4 show that before the bankruptcy, a growing number of financial ratios that differ between bankrupt companies with companies sustained.

Table 3: Comparison of Average Financial Ratios (1997-2001)

\begin{tabular}{|c|c|c|c|c|c|}
\hline \multirow{2}{*}{ Num } & \multirow{2}{*}{ Financial Ratios } & \multirow{2}{*}{ Var. } & \multicolumn{3}{|c|}{ Average } \\
\hline & & & Sustained & $\langle/\rangle$ & Bankrupt \\
\hline 1 & Current Assets to Current Liabilities & $\mathrm{x} 1$ & 1,512201 & $>$ & 0,477415 \\
\hline 2 & Quick Assets to Current Liabilities & $x 2$ & 1,015383 & $>$ & 0,297805 \\
\hline 3 & Gross Profit to Sales & $\times 3$ & 0,275181 & $>$ & 0,171593 \\
\hline 4 & Net Income to Sales & $x 4$ & $-0,15214$ & $>$ & $-0,6237$ \\
\hline 5 & Sales to Total Assets & $x 6$ & 0,781001 & $>$ & 0,662808 \\
\hline 6 & Sales to Fixed Assets & $\mathrm{x} 7$ & 3,030421 & $>$ & 2,676434 \\
\hline 7 & $\begin{array}{l}\text { Earnings Before Interest and Taxes } \\
\text { to Total Assets }\end{array}$ & $x 8$ & $-0,0287$ & $>$ & $-0,20905$ \\
\hline 8 & Net Income to Total Assets & $x 9$ & $-0,03145$ & $>$ & $-0,19275$ \\
\hline 9 & Total Liabilities to Total Assets & $\mathrm{x} 10$ & 0,7671 & $<$ & 1,30047 \\
\hline
\end{tabular}

Source: Results of Research Data Processing, 2014

Table 4: Summary Results Test of Difference

\begin{tabular}{|c|c|c|c|c|c|c|c|c|}
\hline \multirow{2}{*}{ Num } & \multirow{2}{*}{ Financial Ratios } & \multirow{2}{*}{ Var } & \multicolumn{6}{|c|}{ Years } \\
\hline & & & 1997 & 1998 & 1999 & 2000 & 2001 & Overall \\
\hline 1 & $\begin{array}{l}\text { Current Assets to } \\
\text { Current Liabilities }\end{array}$ & $x 1$ & $x$ & $\sqrt{ }$ & $\sqrt{ }$ & $\sqrt{ }$ & $\sqrt{ }$ & $\sqrt{ }$ \\
\hline 2 & $\begin{array}{l}\text { Quick Assets to } \\
\text { Current Liabilities }\end{array}$ & $x 2$ & $x$ & $\sqrt{ }$ & $\sqrt{ }$ & $\sqrt{ }$ & $\sqrt{ }$ & $\sqrt{ }$ \\
\hline 3 & Gross Profit to Sales & $x 3$ & $x$ & $\sqrt{ }$ & $\sqrt{ }$ & $\sqrt{ }$ & $\sqrt{ }$ & $\sqrt{ }$ \\
\hline 4 & Net Income to Sales & $x 4$ & $x$ & $x$ & $\sqrt{ }$ & $\sqrt{ }$ & $\sqrt{ }$ & $\sqrt{ }$ \\
\hline 5 & $\begin{array}{l}\text { Cost of Goods Sold to } \\
\text { Inventory }\end{array}$ & $x 5$ & $x$ & $x$ & $x$ & $x$ & $x$ & $\sqrt{ }$ \\
\hline 6 & Sales to Total Assets & $x 6$ & $x$ & $x$ & $x$ & $x$ & $\sqrt{ }$ & $x$ \\
\hline 7 & Sales to Fixed Assets & $x 7$ & $x$ & $x$ & $x$ & $x$ & $x$ & $\sqrt{ }$ \\
\hline 8 & $\begin{array}{l}\text { Earnings Before Interest } \\
\text { and Taxes to Total } \\
\text { Assets }\end{array}$ & x8 & $x$ & $x$ & $\sqrt{ }$ & $\sqrt{ }$ & $\sqrt{ }$ & $\sqrt{ }$ \\
\hline 9 & $\begin{array}{l}\text { Net Income to } \\
\text { Total Assets }\end{array}$ & x9 & $x$ & $x$ & $\sqrt{ }$ & $\sqrt{ }$ & $\sqrt{ }$ & $\sqrt{ }$ \\
\hline 10 & $\begin{array}{l}\text { Total Liabilities to } \\
\text { Total Assets }\end{array}$ & $x 10$ & $x$ & $\sqrt{ }$ & $\sqrt{ }$ & $\sqrt{ }$ & $\sqrt{ }$ & $\sqrt{ }$ \\
\hline
\end{tabular}

Source: Results of Research Data Processing, 2014 
$\mathrm{x}=$ non-significant

$\sqrt{ }=$ significant

\section{a. The Results of Overall Logistic Regression Test (1997-2001)}

The results of logistic regression calculation of the financial ratios for 5 years (1997-2001) shows that the function of the logistic regression equation is as follows:

$$
\mathrm{p}=\frac{1}{1+\mathrm{e}^{-\left(-1,765-1,025 \mathrm{X}_{1}+2,686 \mathrm{X}_{10}\right)}}
$$

In which:

$\mathrm{p} \quad=$ The probability of bankruptcy

$\mathrm{X}_{1} \quad=$ Current Asset to Current Liabilities (CACL)

$\mathrm{X}_{10}=$ Total Liabilities to Total Assets (TLTA)

The accuracy of the logistic regression model (for 5 years) can be identified by cross-checking the results of model predictions with data from observations/sample. Test models done by entering each value of the variable $x$ from the sample data to the model above. Using a cut-off value of 0.5 obtained cross-check the results of the performance of the model as presented in Table 5.

Table 5: Performance of Logistic Regression Models (1997-2001)

\begin{tabular}{|c|c|c|c|}
\hline \multirow{2}{*}{ Observe } & \multicolumn{2}{|c|}{ Prediction } & \multirow{2}{*}{ Accuracy (\%) } \\
\cline { 2 - 3 } & Sustained & Bankrupt & 79,00 \\
\hline \hline Sustained & 79 & 21 & 74,00 \\
\hline Bankrupt & 26 & 74 & 76,50 \\
\hline
\end{tabular}

Source: Results of Research Data Processing, 2014

Table 5 shows that the 100 non-bankrupt company data, there are 79 corporate data $(79.00 \%)$ which classified correctly by the model, while the data of 100 bankrupt companies are corporate data 74 $(74.00 \%)$ were classified correctly by the model. So the overall the percentage of companies that are classified correctly by the logistic regression model simultaneously is $76.50 \%$.

Table 6: Resume Financial Ratios Influential Toward Bankruptcy

\begin{tabular}{|c|c|c|c|c|c|}
\hline Num. & Year & $\begin{array}{l}\text { Year Before } \\
\text { Bankrupt }\end{array}$ & Var. & Financial Ratios & Group \\
\hline 1 & 1997 & 5 & - & - & - \\
\hline \multirow[t]{2}{*}{2} & \multirow[t]{2}{*}{1998} & \multirow[t]{2}{*}{4} & $X_{2}$ & $\begin{array}{l}\text { Quick Assets to Current } \\
\text { Liabilities (QACL) }\end{array}$ & Liquidity \\
\hline & & & $X_{3}$ & Gross Profit to Sales (GPS) & Profitability \\
\hline \multirow[t]{2}{*}{3} & \multirow[t]{2}{*}{1999} & \multirow[t]{2}{*}{3} & $X_{1}$ & $\begin{array}{l}\text { Current Assets to Current } \\
\text { Liabilities (CACL) }\end{array}$ & Liquidity \\
\hline & & & $\mathrm{X}_{3}$ & Gross Profit to Sales (GPS) & Profitability \\
\hline
\end{tabular}




\begin{tabular}{|c|c|c|c|c|c|}
\hline 4 & 2000 & 2 & $X_{8}$ & $\begin{array}{c}\text { Earnings Before Interest and } \\
\text { Taxes to Total Assets (EBITTA) }\end{array}$ & ROI \\
\hline 5 & 2001 & 1 & $X_{10}$ & $\begin{array}{c}\text { Total Liabilities to Total Assets } \\
\text { (TLTA) }\end{array}$ & Leverage \\
\hline 6 & Overall & - & $X_{1}$ & $\begin{array}{c}\text { Current Asset to Current } \\
\text { Liabilities (CACL) }\end{array}$ & Liquidity \\
\cline { 3 - 6 } & & $X_{10}$ & $\begin{array}{c}\text { Total Liabilities to Total Assets } \\
\text { (TLTA) }\end{array}$ & Leverage \\
\hline
\end{tabular}

Source: Results of Research Data Processing, 2014

\section{b. Financial Ratios Dominant Influence the Company Bankruptcy}

To determine financial ratios dominant influence the bankruptcy using logistic regression analysis of all financial ratio data for 5 years with the enter method. By using logistic regression method, model is obtained as follows:

$$
\mathrm{p}=\frac{1}{1+\mathrm{e}^{-\left(-0,883-2,191 \mathrm{X}_{1}+1,486 \mathrm{X}_{2}-1,866 \mathrm{X}_{3}-0,485 \mathrm{X}_{4}-0,019 \mathrm{X}_{5}+0,320 \mathrm{X}_{6}-0,041 \mathrm{X}_{7}-1,412 \mathrm{X}_{8}+2,007 \mathrm{X}_{9}+2,280 \mathrm{X}_{10}\right)}}
$$

Table 7: Testing Logistic Regression Coefficients By Individual (Phase I)

\begin{tabular}{|c|c|c|c|c|}
\hline Hypothesis & Wald & $\mathrm{Db}$ & p-value & Results \\
\hline $\begin{array}{l}\mathrm{H}_{0}: \beta_{0}=0 \\
\mathrm{H}_{0}: \beta_{0} \neq 0\end{array}$ & .788 & 1 & .375 & Non-Sig \\
\hline $\begin{array}{l}\mathrm{H}_{0}: \beta_{1}=0 \\
\mathrm{H}_{0}: \beta_{1} \neq 0\end{array}$ & 3.881 & 1 & .049 & Sig \\
\hline $\begin{array}{l}\mathrm{H}_{0}: \beta_{2}=0 \\
\mathrm{H}_{0}: \beta_{2} \neq 0\end{array}$ & 1.309 & 1 & .253 & Non-Sig \\
\hline $\begin{array}{l}H_{0}: \beta_{3}=0 \\
H_{0}: \beta_{3} \neq 0\end{array}$ & 2.879 & 1 & .090 & Non-Sig \\
\hline $\begin{array}{l}\mathrm{H}_{0}: \beta_{4}=0 \\
\mathrm{H}_{0}: \beta_{4} \neq 0\end{array}$ & .791 & 1 & .374 & Non-Sig \\
\hline $\begin{array}{l}\mathrm{H}_{0}: \beta_{5}=0 \\
\mathrm{H}_{0}: \beta_{5} \neq 0\end{array}$ & .497 & 1 & .481 & Non-Sig \\
\hline $\begin{array}{l}\mathrm{H}_{0}: \beta_{6}=0 \\
\mathrm{H}_{0}: \beta_{6} \neq 0\end{array}$ & .370 & 1 & .543 & Non-Sig \\
\hline
\end{tabular}




\begin{tabular}{|l|c|c|c|c|}
\hline $\mathrm{H}_{0}: \beta_{7}=0$ & .923 & 1 & .337 & Non-Sig \\
$\mathrm{H}_{0}: \beta_{7} \neq 0$ & .212 & 1 & .645 & Non-Sig \\
\hline $\mathrm{H}_{0}: \beta_{8}=0$ & .423 & 1 & .515 & Non-Sig \\
$\mathrm{H}_{0}: \beta_{8} \neq 0$ & & 1 & .012 & Sig \\
\hline $\mathrm{H}_{0}: \beta_{9}=0$ & 6.288 & 1 & & \\
$\mathrm{H}_{0}: \beta_{9} \neq 0$ & & & & \\
\hline $\mathrm{H}_{0}: \beta_{10}=0$ & & & & \\
$\mathrm{H}_{0}: \beta_{10} \neq 0$ & & & & \\
\hline
\end{tabular}

Source: Results of Research Data Processing, 2014

Model fit test was conducted to determine the suitability of the results of the model predictions with data from observations using the Hosmer-Lameshow test statistics. Under this test values obtained significant opportunities to match the model of 0.198 . Hosmer-value opportunities significance Lameshow more than 0.05 means that the model is fit to have a fit between the observed data with data from model predictions. On this basis it can be stated that in overalls declared fit models. After testing in overalls further testing individually for regression coefficients using the Wald test statistic. Test results using the Wald test statistics are presented in the table 7.

Table 7 shows the result that the financial ratios that significantly in determining bankruptcy is a financial ratio $X_{1}$ (Current Assets to Current Liabilities) and $X_{10}$ (Total Liabilities to Total Assets). While other financial ratios revealed no significant influence. Because they logistic regression model involving all financial ratios still involve variables are not significant financial ratios, then before examined the performance of the model, first look for the best regression model for logistic regression models simultaneously this.

To find the best logistic regression model reached by using backward through the Wald test statistic. Backward method that reduces the model by eliminating variables that are not significant. The result of this process produces a logistic regression model as follows:

$$
\mathrm{p}=\frac{1}{1+\mathrm{e}^{-\left(-1,765-1,025 \mathrm{X}_{1}+2,686 \mathrm{X}_{10}\right)}}
$$

The probability of significance for the above model fit using the Hosmer-Lameshow test statistic obtained for 0.320 . With the probability of significance over 0.05 model fit the above model declared fit to the data. Significance test results for individual regression coefficients on the new model are shown in the following table 8.

Tabel 8: Testing Logistic Regression Coefficients By Individual (Phase II) 


\begin{tabular}{|l|c|c|c|c|}
\hline \multicolumn{1}{|c|}{ Hipotesis } & Wald & Db & p-value & Result \\
\hline $\mathrm{H}_{0}: \beta_{0}=0$ & 7.874 & 1 & .005 & Sig. \\
$\mathrm{H}_{0}: \beta_{0} \neq 0$ & 14.560 & 1 & .000 & Sig. \\
\hline $\mathrm{H}_{0}: \beta_{1}=0$ & & & & \\
$\mathrm{H}_{0}: \beta_{1} \neq 0$ & 4.794 & 1 & .029 & Sig. \\
\hline $\mathrm{H}_{0}: \beta_{2}=0$ & & & & \\
$\mathrm{H}_{0}: \beta_{2} \neq 0$ & & & & \\
\hline
\end{tabular}

Source: Results of Research Data Processing, 2014

Table 8 shows that the value of the significance of individual test results to a new logistic regression model resulted in significant testing. This is evident from the significance probability value less than 0.05. Logistic regression model above shows a significant effect of $X_{1}$ and $X_{10}$ towards bankruptcy. Based on the best regression model formed as above, can be explained that:

1. There is a significant influence of financial ratios Current Assets to Current Liabilities $\left(X_{1}\right)$ to bankruptcy. Based on the magnitude of the regression coefficients for $X_{1}$, it means that any increase in the value of financial ratios for the unit then the chances of the company entered bankruptcy category will decrease (negative sign) of $\mathrm{e}^{1,025}=2.787$, and;

2. There is a significant effect of financial ratios Total Liabilities to Total Assets $\left(X_{10}\right)$ to bankruptcy. Based on the magnitude of the regression coefficient for the $X_{10}$, it means that any increase in the value of financial ratios for the unit then the chances of the company entered bankruptcy category will increase by $e^{2,686}=14.673$.

\section{CONCLUSIONS}

1) There are significant differences between the financial ratios of the company insolvent with a company that is not insolvent. Financial ratios of liquidity, profitability, activity, and return on investment of companies which are not insolvent proved greater than the company insolvent. While the leverage ratio (total liabilities to total assets) companies which are not insolvent is smaller than the company insolvent. The results of this study also indicate that the closer bankruptcy, more and more financial ratios that show significant differences between the companies insolvent with a company that is not insolvent.

2) Financial ratios proved to be utilized as a tool for predicting bankruptcy of the company, including the circumstances that a relatively high degree of uncertainty as the economic crisis. The results of this study showed that the overall level of predictive validity (simultaneously for 5 years) of $76.50 \%$ (overall). While the test results each year is known that the predicted rate established by the logistic regression model for a period of $4,3,2$, and 1 year prior to bankruptcy turned out to be even greater, namely: $77.50 \%, 80.00 \%, 92.50 \%$, and $92.50 \%$. Whereas in 1997 or 5 years before the bankruptcy, not obtained an adequate model. In other words, financial ratios 5 years prior to the bankruptcy can not be used as a predictive tool for bankruptcy.

3) Financial ratios dominant influence on the bankruptcy of the company is the ratio of liquidity and leverage. The results of this study prove that from 10 financial ratios tested, there are 
two financial ratios of the most dominant in shaping the bankruptcy models, namely Current Assets to Current Liabilities and Total Liabilities to Total Assets.

\section{Recommendations}

1) There is evidence that financial ratios have reliability in predicting bankruptcy can be a valuable reference for financial policy makers. Financial ratios can be used as an early warning tool (early warning system) in anticipation of bankruptcy in the future;

2) The model of predictions are generated in this study were tested in companies that research sample. Therefore, it is possible to have a prediction accuracy rate is too high. Therefore, it is suggested that other researchers to test it on other companies that are not sampled in this study, and testing was conducted for a period of time that will come.

3) This study focuses only on 10 types of financial ratios calculation basis balance sheet and income statement. For it to other researchers suggested that developing a type of financial ratios are examined, including financial ratios include the basic calculation of the cash flow and market value (stock);

4) For investors, financial ratios can be valuable information in making investment decisions. If the state of the company has been showing a state where a low level of liquidity or high leverage, then this situation can mean "warning" that investors shift their investment immediately, because liquidity is low and or high leverage can be an indication of impending bankruptcy. 


\section{References}

Ahnaf, Mohammad Iqbal. 2016. "Tiga Jalan Islam Politik Di Indonesia: Reformasi, Refolusi Dan Revolusi." Wawasan: Jurnal IImiah Agama Dan Sosial Budaya 1 (2): 1. doi:10.15575/jw.v1i2.728.

Akhyar, Adnan Muhammad, and Muhammad Imam Taufiq. 2001. "Analisis Ketepatan Prediksi Metode Altman Terhadap Terjadinya Likuiditas Pada Lembaga Perbankan." Jurnal Akuntansi \& Auditing Indonesia 5 (2).

Altman, Edwar I. 1968. "Financial Ratio, Discriminant Analysis and The Prediction of Corporate Bankruptcy." The Journal of Finance.

Avianti, llya. 2000. "Model Prediksi Kepailitan Emiten Di Bursa Efek Jakarta Dengan Menggunakan Indikator-Indikator Keuangan." PPS Universitas Padjadjaran Bandung.

Badri Khaeruman. 2016. "Al Qardawi Dan Orientasi Pemikiran Hukum Islam Untuk Menjawab Tuntutan Perubahan Sosial." Wawasan: Jurnal IImiah Agama Dan Sosial Budaya 1 (2): 1.

Beaver, William H. 1966. "Financial Ratio as Predictors of Failure."

Dambolena, Ismael G, and Khoury. 1980. "Ratio Stability and Corporate Failure." The Journal of Finance XXX (4).

Mas'ud, Machfoedz. 1994. Financial Ratio Analysis and The Prediction of Earning Changes in Indonesia.

Pankoff, and Virgil. 1970. "On The Usefullness of Financial Statement Information."

Sinkey, Joseph F. 1975. "A Multivariate Statistical Analysis of The Characteristics of Problem Banks." The Journal of Financel of Finance XXX (1).

Surifah. 1999. "Perbedaan Bank Terlikuidasi Dan Bank Tidak Terlikuidasi Suatu Studi Terhadap Elemen-Elemen Laporan Keuangan." Kajian Bisnis 19.

Thomson. 1991. "Predicting Bank Failure in 1980's." In Economic Review, second Qua.

Whalen, and Thomson. 1988. "Using Financial Data to Identify Changes in Bank Condition." , (Second Quarter).

Zain, Sumarno. 1994. "Failure Prediction; An Artificial Intelligence Approach, Accountancy Development in Indonesia." In Publication No.21. Jakarta: Tim Koordinasi Pengembangan Akuntansi. 